\author{
L. I. SOBITNYAK ${ }^{1}$, M. I. RYABOV ${ }^{1}$, M. I. ORLYUK ${ }^{2}$, \\ A. L. SUKHAREV ${ }^{1}$, A. O. ROMENETS ${ }^{2}$, YU. P. SUMARUK ${ }^{2}$, \\ and A. A. PILIPENKO ${ }^{1}$ \\ ${ }^{1}$ Observatory "URAN-4", Institute of Radio Astronomy, \\ National Academy of Sciences of Ukraine, \\ 1v, Marazliivska St., Astronomical Observatory, Odesa, 65014, Ukraine \\ E-mail: ryabov-uran@ukr.net \\ ${ }^{2}$ S. I. Subbotin Institute of Geophysics, National Academy of Sciences of Ukraine, \\ 32, Palladin Ave., Kyiv, 03142, Ukraine \\ E-mail: orlyuk@igph.kiev.ua
}

\title{
ANALYSIS OF THE MAGNETIC STORMS CATALOG FOR MONITORING RADIO SOURCE FLUXE DATA WITH THE URAN-4 RADIO TELESCOPE IN THE ODESA MAGNETIC ANOMALY ZONE
}

\begin{abstract}
Purpose: Compilation of a digital catalog of magnetic storms in the Odesa magnetic anomaly zone in order to find the reasons for possible changes in the radiation fluxes of cosmic radio sources, according to observations at the URAN-4 radio telescope.

Design/methodology/approach: Since 1987 until now, the radio flux of powerful galactic and extragalactic radio sources has been monitored at the URAN-4 radio telescope of the Odesa Observatory of the Institute of Radio Astronomy of the National Academy of Sciences of Ukraine. The monitoring program includes radio galaxies 3C274, 3C405 and supernova remnants 3C144, 3C461. Changes in the radio source flux level are determined by the ionosphere state due to the changes in space weather. At the "Odesa" geomagnetic observatory of the Institute of Geophysics of the National Academy of Sciences of Ukraine, the geomagnetic field measurements have been made since 1948. Simultaneously, the measurements of three elements of the geomagnetic field: horizontal component $(H)$, vertical component $(Z)$ and inclination $(D)$, have been recorded.

Findings: Using the "Odesa" geomagnetic observatory data, the digital catalog of magnetic storms was compiled for the measuring period of the powerful space radio source fluxes obtained with the URAN-4 radio telescope. For the magnetic storms monitored during the periods of 1987-1995 and 2000-2009, the date and time are shown for the beginning and the end of the magnetic storm, the magnetic storm duration, the amplitude of the three magnetic field elements, being $H, Z$, and D, and the magnetic storm type characteristic.The "Odesa" geomagnetic observatory is located near the magnetic anomaly zone. To find the distinctions in manifestations of the geomagnetic activity arisen owing to the magnetic anomaly existence, the geomagnetic disturbances recorded at the "Odesa" and "Moscow" (IZMIRAN, Russia) observatories were compared. It was shown that the total annual duration of the magnetic storms was longer in Odesa than in Moscow. This demonstrates some special role of the magnetic anomaly in the development of geomagnetic disturbances.

Conclusions: The digital catalog of magnetic storms in the Odesa magnetic anomaly zone was compiled for the 1987-1995 and 2000-2009 periods. It is also planned to terminate working over the complete catalog of magnetic storms recorded at the "Odesa" observatory for the entire continuous period of monitoring space radio sources at the URAN-4 radio telescope in order to find the manifestations of geomagnetic disturbances impact upon the ionosphere state and changes of intensity in cosmic radio source fluxes. These studies are supplemented by the comparative analysis of the "Odesa" observatory geomagnetic data and the data from some other geomagnetic observatories.
\end{abstract}

Key words: solar activity, monitoring variability of radio sources, magnetic storms, catalog of magnetic storms, magnetic anomaly

\section{Introduction}

The "Odesa" geomagnetic observatory was founded by the Novorossiysk Imperial University, on the botanical garden area, at the beginning of the XX century. In 1936, it was moved to the village of Stepanivka (near Odesa) by the Odesa State University. After the World War II, the Observatory became to belong to the Institute of Geophysics. Since 1948 till 2010, the analog measurements of the Earth's magnetic field were made at the "Odesa" geomagnetic observatory. At the same time, the measurements of three elements of the magnetic field were recorded: horizontal component $(H)$, vertical component $(Z)$, and inclination $(D)$, based on which the magnetic storms data were given in a tabular form [1]. Fig. 1 shows a monthly review of the magnetic field state in November 2003. The content of the catalog is presented in paper [2]. 


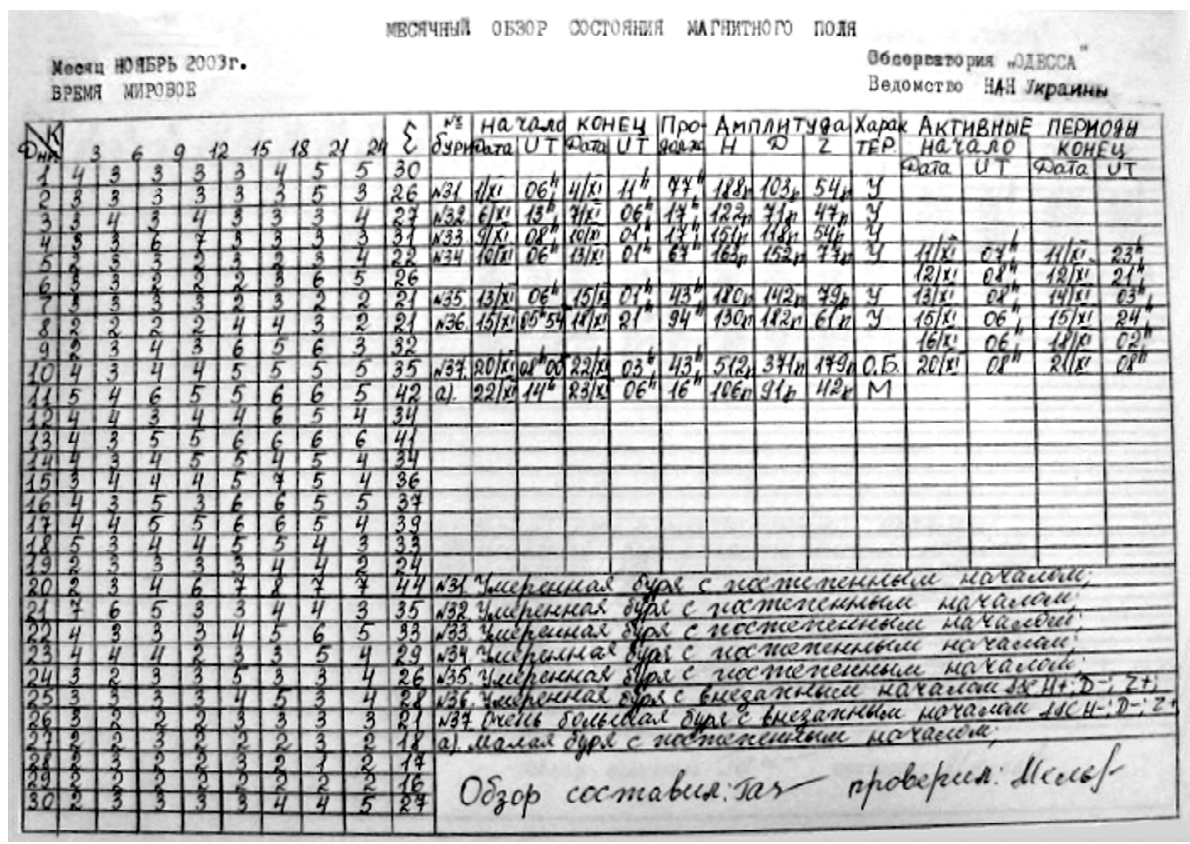

Fig. 1. Overview of the magnetic field state in November 2003

\section{Catalog of magnetic storms}

Using the "Odesa" geomagnetic observatory data, the magnetic storms catalog was made. This cata$\log$ issue for the 1987-1995 and 2000-2009 years include: the date and time of the beginning and the end of a storm, the storm duration, the amplitude of the magnetic field $H, Z$, and $D$ components, and the characteristics of magnetic storms with the indication of the fissile periods. As an example, the observational data of the "Odesa" geomagnetic observatory for the period of January-March 2003 are given in Table 1. The total number of minor, moderate, strong and extreme storms are shown in Table 2 and Fig. 2.

The catalog was compiled to identify the reasons for the change in the space radio sources' flux level, according to the observations made since 1987 with the Odesa Observatory URAN-4 radio telescope of the Institute of Radio Astronomy of the National Academy of Sciences of Ukraine. The data on powerful radio source flux changes during the periods of extreme states of solar activity are given in [3]. Paper [3] also presents the results of calculating multiple correlation analysis models, which show the dependence of the radio source flux changes on the main indices characterizing the space weather state.

\section{Magnetic anomaly zone}

The "Odesa" geomagnetic observatory is located near the intensive magnetic anomaly. Since the dome of the geomagnetic field extends to the altitudes of about $90 \mathrm{~km}$ into the ionosphere layer, where the variation (rapidly variable) component of the geomagnetic field is formed, the regional magnetic anomalies can affect the manifestation of the geomagnetic field variability. When processing the long-term observations data, the magnetic anomaly influence on the geomagnetic activity was found. The map of the anomalous geomagnetic field distribution near the Odesa city is shown in Fig. 3.

To identify the magnetic anomaly influence on geomagnetic activity, the magnetic storms characteristics were compared according to the "Odesa" and "Moscow" (IZMIRAN, Russia) geomagnetic observatories data. The total duration of all magnetic storms throughout the year in Odesa is longer than in Moscow (see Fig. 4). Table 3 provides information on the duration of individual magnetic storms in the "Odesa" and "Moscow" geomagnetic observatories' areas for 1987-1995 and 2001-2003.

Since 2017 till 2019, right in the center of the magnetic anomaly on the area of the Astronomical Observatory of the Odesa I. I. Mechnikov National University, the magnetic field variations were mea- 
Table 1. Digital catalog of magnetic storms and their characteristics

\begin{tabular}{|c|c|c|c|c|c|c|c|c|c|c|c|c|c|}
\hline \multirow{2}{*}{\multicolumn{2}{|c|}{ Beginning }} & \multirow{2}{*}{\multicolumn{2}{|c|}{ End }} & \multirow{3}{*}{$\begin{array}{l}\text { Dura- } \\
\text { tion, } \mathrm{h}\end{array}$} & \multirow{2}{*}{\multicolumn{3}{|c|}{ Amplitude }} & \multirow{3}{*}{$\begin{array}{l}\text { Storm } \\
\text { class }\end{array}$} & \multicolumn{4}{|c|}{ Active periods } & \multirow{3}{*}{ Comments } \\
\hline & & & & & & & & & \multicolumn{2}{|c|}{ beginning } & \multicolumn{2}{|l|}{ end } & \\
\hline date & UT & date & UT & & $H$ & $D$ & $Z$ & & date & UT & date & UT & \\
\hline 03.01 .2003 & $12: 00$ & 04.01 .2003 & $0: 00$ & 36 & 95 & 94 & 36 & minor & & & & & $\begin{array}{l}\text { Minor storm } \\
\text { with the gradual } \\
\text { beginning }\end{array}$ \\
\hline 18.01.2003 & $6: 00$ & 20.01 .2003 & $6: 00$ & 48 & 105 & 64 & 39 & minor & & & & & $\begin{array}{l}\text { Minor storm } \\
\text { with the gradual } \\
\text { beginning }\end{array}$ \\
\hline 20.01.2003 & $10: 00$ & 23.01 .2003 & 4:00 & 66 & 98 & 68 & 38 & minor & & & & & $\begin{array}{l}\text { Minor storm } \\
\text { with the gradual } \\
\text { beginning }\end{array}$ \\
\hline 29.01 .2003 & 9:00 & 30.01 .2003 & $20: 00$ & 35 & 116 & 124 & 42 & moderate & & & & & $\begin{array}{l}\text { Moderate storm } \\
\text { with the gradual } \\
\text { beginning }\end{array}$ \\
\hline 01.02 .2003 & $15: 00$ & 05.02 .2003 & 3:00 & 84 & 176 & 145 & 82 & moderate & $\begin{array}{l}01.02 .2003 \\
03.02 .2003\end{array} \mid$ & $\begin{array}{l}18: 00 \\
12: 00\end{array}$ & $\begin{array}{l}03.02 .2003 \\
04.02 .2003\end{array}$ & $\begin{array}{c}2: 00 \\
12: 00\end{array}$ & $\begin{array}{l}\text { Moderate storm } \\
\text { with the gradual } \\
\text { beginning }\end{array}$ \\
\hline 08.02 .2003 & $7: 00$ & 09.02 .2003 & 3:00 & 20 & 75 & 70 & 26 & minor & & & & & $\begin{array}{l}\text { Minor storm } \\
\text { with the gradual } \\
\text { beginning }\end{array}$ \\
\hline 12.02 .2003 & $8: 00$ & 13.02 .2003 & $1: 00$ & 17 & 83 & 74 & 26 & minor & & & & & $\begin{array}{l}\text { Minor storm } \\
\text { with the gradual } \\
\text { beginning }\end{array}$ \\
\hline 13.02 .2003 & $21: 00$ & 15.02 .2003 & 21:00 & 48 & 80 & 105 & 35 & minor & 14.02.2003 & 9:00 & 15.02 .2003 & $18: 00$ & $\begin{array}{l}\text { Minor storm } \\
\text { with the gradual } \\
\text { beginning }\end{array}$ \\
\hline 16.02.2003 & $6: 00$ & 17.02 .2003 & $2: 00$ & 20 & 86 & 62 & 32 & minor & & & & & $\begin{array}{l}\text { Minor storm } \\
\text { with the gradual } \\
\text { beginning }\end{array}$ \\
\hline 26.02.2003 & $6: 00$ & 28.02 .2003 & $1: 00$ & 43 & 106 & 114 & 48 & moderate & & & & & $\begin{array}{l}\text { Moderate storm } \\
\text { with the gradual } \\
\text { beginning }\end{array}$ \\
\hline 28.02.2003 & $6: 00$ & 01.03 .2003 & 3:00 & 21 & 93 & 85 & 42 & minor & & & & & $\begin{array}{l}\text { Minor storm } \\
\text { with the gradual } \\
\text { beginning }\end{array}$ \\
\hline 03.03 .2003 & $15: 00$ & 05.03 .2003 & $3: 00$ & 36 & 92 & 131 & 57 & moderate & & & & & $\begin{array}{l}\text { Moderate storm } \\
\text { with the gradual } \\
\text { beginning }\end{array}$ \\
\hline 05.03 .2003 & 9:00 & 07.03 .2003 & $12: 00$ & 51 & 103 & 96 & 46 & minor & & & & & $\begin{array}{l}\text { Minor storm } \\
\text { with the gradual } \\
\text { beginning }\end{array}$ \\
\hline 20.03.2003 & $6: 00$ & 22.03 .2003 & $2: 00$ & 44 & 119 & 101 & 50 & moderate & & & & & $\begin{array}{l}\text { Moderate storm } \\
\text { with the gradual } \\
\text { beginning }\end{array}$ \\
\hline 22.03.2003 & $19: 00$ & 24.03 .2003 & $2: 00$ & 31 & 106 & 85 & 32 & minor & & & & & $\begin{array}{l}\text { Minor storm } \\
\text { with the gradual } \\
\text { beginning }\end{array}$ \\
\hline 28.03.2003 & $16: 00$ & 31.03 .2003 & $3: 00$ & 59 & 98 & 124 & 81 & moderate & & & & & $\begin{array}{l}\text { Moderate storm } \\
\text { with the gradual } \\
\text { beginning }\end{array}$ \\
\hline 31.03 .2003 & $6: 00$ & 01.04 .2003 & $4: 00$ & 22 & 127 & 111 & 62 & moderate & & & & & $\begin{array}{l}\text { Moderate storm } \\
\text { with the gradual } \\
\text { beginning }\end{array}$ \\
\hline
\end{tabular}


Table 2. Number of magnetic storms in the catalog for 1987-1995 and 2000-2009

\begin{tabular}{|c|c|c|c|c|}
\hline Period & $\begin{array}{c}\text { Minor } \\
\text { storm }\end{array}$ & $\begin{array}{c}\text { Moderate } \\
\text { storm }\end{array}$ & $\begin{array}{c}\text { Strong } \\
\text { storm }\end{array}$ & $\begin{array}{c}\text { Extreme } \\
\text { storm }\end{array}$ \\
\hline 1987 & 21 & 19 & 0 & 0 \\
1988 & 41 & 16 & 7 & 1 \\
1989 & 28 & 38 & 8 & 4 \\
1990 & 24 & 34 & 7 & 1 \\
1991 & 19 & 25 & 9 & 9 \\
1992 & 31 & 26 & 7 & 1 \\
1993 & 27 & 23 & 8 & 0 \\
1994 & 19 & 9 & 7 & 1 \\
1995 & 23 & 20 & 1 & 0 \\
2000 & 25 & 16 & 5 & 3 \\
2001 & 31 & 27 & 4 & 6 \\
2002 & 39 & 21 & 4 & 2 \\
2003 & 38 & 36 & 1 & 2 \\
2004 & 31 & 11 & 4 & 2 \\
2005 & 30 & 16 & 5 & 4 \\
2006 & 32 & 9 & 1 & 0 \\
2007 & 34 & 5 & 0 & 0 \\
2008 & 28 & 4 & 0 & 0 \\
2009 & 11 & 0 & 0 & 0 \\
\hline
\end{tabular}

sured with the LEMI-008 precision flux gate magnetometer of the S. I. Subbotin Institute of Geophysics of the National Academy of Sciences of Ukraine. The measurements were made with a second resolution time. As a result, the data on rapid variability of the geomagnetic field $H, Z$, and $D$ components, lasting for more than 1 year, were obtained. The dependences of the time-frequency wavelet spectra on geomagnetic storms of different strengths and caused by different active processes on the Sun have been studied. These properties (amplitudes of geomagnetic variations in the bands of individual quasiperiods, changes in quasi-periods over time and at the moments of storms, disturbances, and geomagnetic quiet days, changes in the spectral power density of time series with time that shows the "overlap" of different fluctuations for the same, quite short periods of time) are compared with the properties of fast geomagnetic variations obtained on the "Dymer" geomagnetic observatory area, Kyiv region, where the geomagnetic field is very close to normal. It is shown that there are significant differences between the type of digital spectra for the "Odesa" and the "Dymer", and between the properties of variations in the geomagnetic field. Thus, in the "Odesa" data, the short-period component of variations is more prominent, the fluctuations with periods of up to 4-5 min are reliably distinguished, and up to 3 minutes on low-noise days. These variations are often quasiperiodic during the geomagnetic storms. According to the "Dymer" observatory data, the quasiperiodic variations are mainly concentrated in the low-frequency region of digital spectra, in the period band of 12-30 min. Sometimes there are complex transitions of oscillation periods, which have a characteristic "grid" shape on the digital spectrum, usually in the bands of periods from 5 to $20 \mathrm{~min}$, and usually observed at night and in the morning. However, this occurs quite rarely. Usually, the geomagnetic variations according to the "Dymer" observatory data become noisy in the band of periods less than 13 min. Thus, the "prints" of geomagnetic storms and disturbed days are different for the areas of anomalous field ("Odesa") and for a calm field

Number of magnetic storms

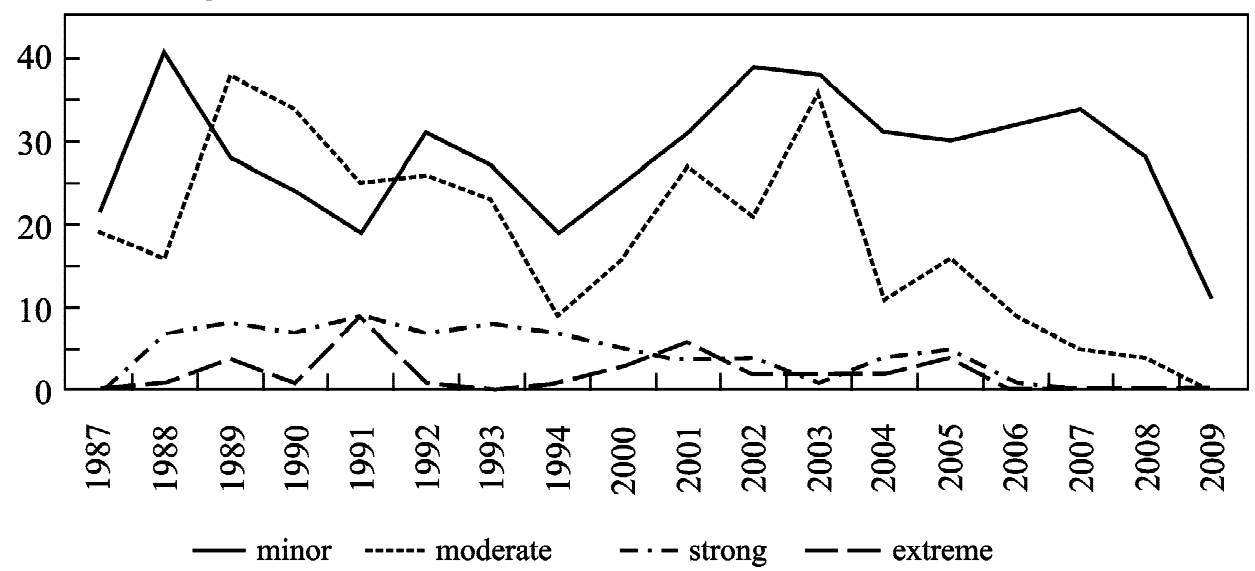

Fig. 2. Graphical representation of the number of magnetic storms in the catalog 


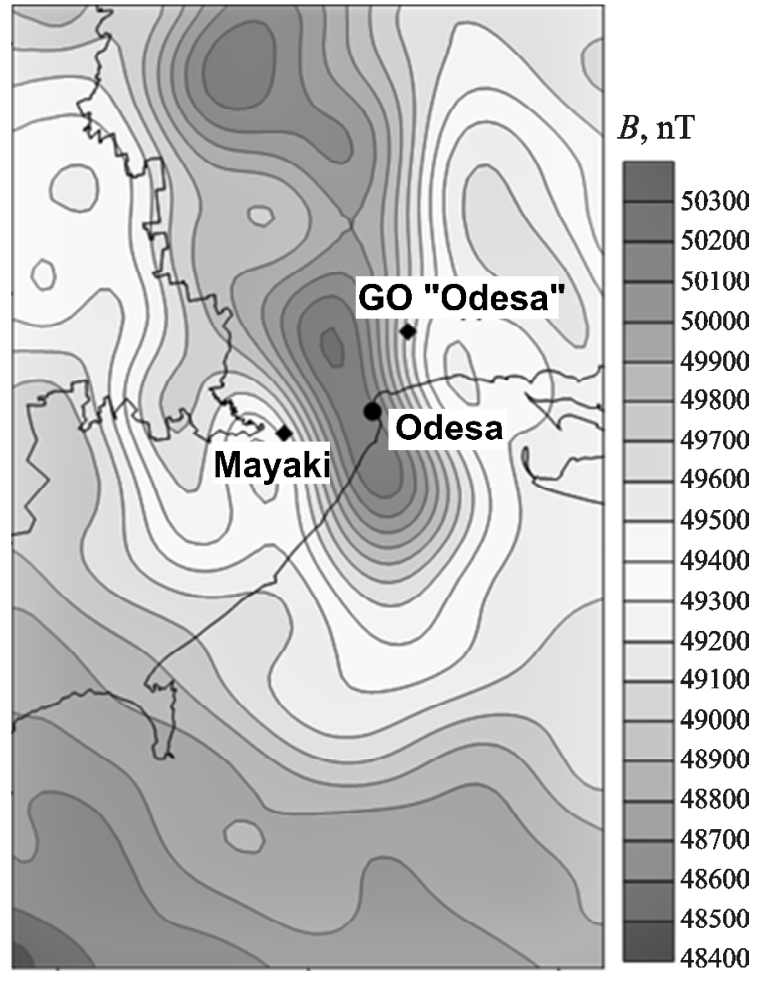

Fig. 3. Map of the Earth's magnetic field induction module distribution in the Odesa area in 2015

("Dymer"). Some results of the analysis of shortperiod geomagnetic variations are given in $[4,5]$. Taking into account the fact that in the Odesa regional magnetic anomaly area there is the URAN-4 lowfrequency radio telescope (phased antenna array) of the decameter $(10-30 \mathrm{MHz})$ wavelength range, the study of the relationship and differences between the ionosphere scintillations of powerful galactic and extragalactic radio sources (on a cloud of homogeneities) and the rapid variations in the geomagnetic field, since both of these phenomena are consequence of ionosphere processes. The Odesa Regional Magnetic Anomaly is a unique "natural laboratory" in Ukraine and studying its connection with the ionosphere will continue.

\section{Conclusions}

1. Using the "Odesa" geomagnetic observatory data, the catalog of the magnetic storms is made. This issue of the catalog for 1987-1995 and 2000-2009 include: date and time of the beginning and the end of a storm, the storm duration, amplitude of the magnetic field $H, Z$, and $D$ components, the characteristic of magnetic storms.

2. The comparison of the magnetic storms duration recorded at the "Odesa" geomagnetic observatory is longer than that obtained at "Moscow" (IZMIRAN).

3 . It is planned to create the catalog of magnetic storms according to the "Odesa" observatory data obtained for the entire monitoring period of space radio sources at the URAN-4 radio telescope in order to identify the manifestations of geomagnetic disturbances during radio astronomical observations and their contribution to changes in radio source fluxes at decameter waves.

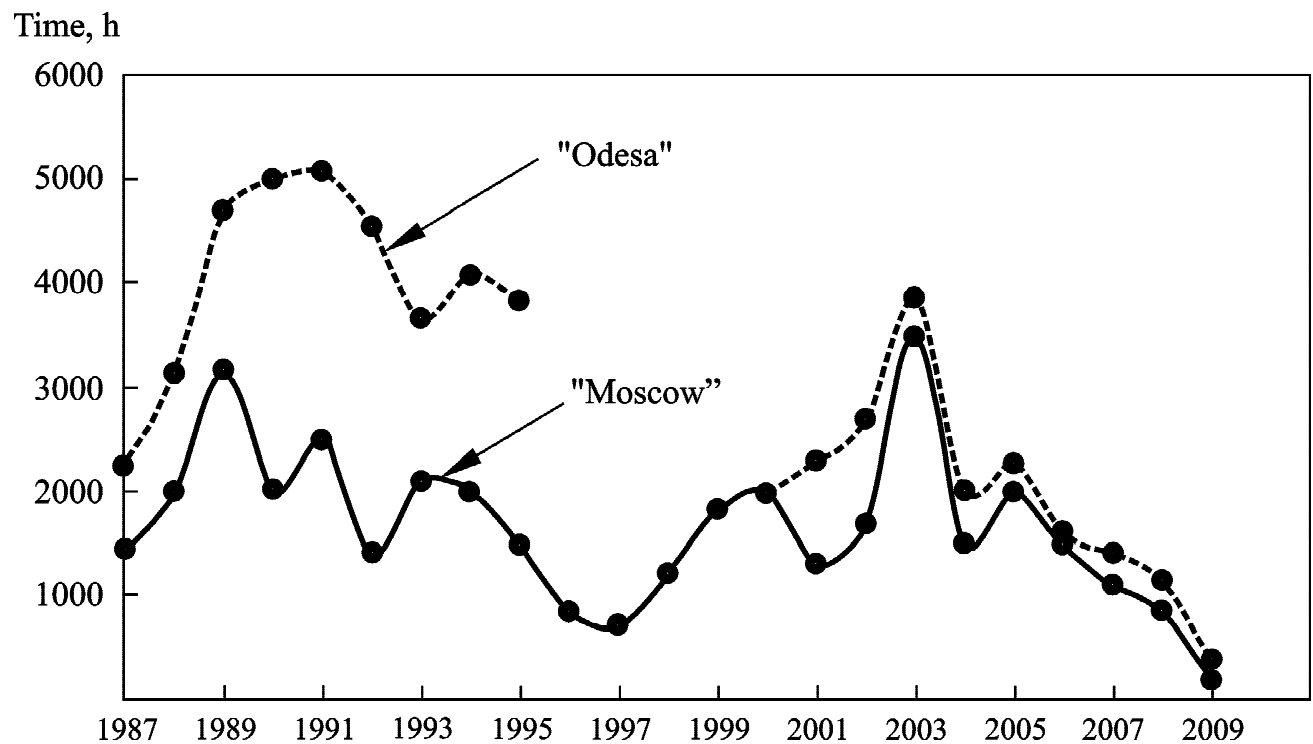

Fig. 4. The total annual duration of magnetic storms according to the "Odesa" and "Moscow" geomagnetic observatories data 
Table 3. The most intense magnetic storms duration according to the "Odesa" and "Moscow" geomagnetic observatories data for 2001-2003

\begin{tabular}{|c|c|c|}
\hline Date & $\begin{array}{c}\text { Duration, } \mathrm{h} \\
\text { "Odesa" }\end{array}$ & $\begin{array}{c}\text { Duration, } \mathrm{h} \\
\text { "Moscow" }\end{array}$ \\
\hline 19.03 .2001 & 38 & 40 \\
28.03 .2001 & 35 & 28 \\
31.03 .2001 & 70 & 9 \\
08.04 .2001 & 35 & 24 \\
11.04 .2001 & 29 & 18 \\
18.04 .2001 & 34 & 10 \\
17.08 .2001 & 36 & 8 \\
21.10 .2001 & 48 & 4 \\
05.11 .2001 & 62 & 40 \\
10.01 .2002 & 89 & 30 \\
17.04 .2002 & 43 & 21 \\
19.04 .2002 & 39 & 9 \\
11.05 .2002 & 30 & 22 \\
23.05 .2002 & 12 & 9 \\
01.08 .2002 & 88 & 26 \\
01.10 .2002 & 45 & 61 \\
03.10 .2002 & 65 & 50 \\
02.11 .2002 & 125 & 20 \\
24.04 .2003 & 108 & 41 \\
26.06 .2003 & 102 & 41 \\
15.07 .2003 & 52 & 2 \\
28.07 .2003 & 157 & 40 \\
20.08 .2003 & 116 & 56 \\
15.09 .2003 & 127 & 56 \\
16.10 .2003 & 91 & 40 \\
15.11 .2003 & 94 & 9 \\
20.11 .2003 & 43 & \\
& & 5 \\
\hline
\end{tabular}

4. These studies will be supplemented by a comparative analysis of the characteristics of magnetic storms in the magnetic anomaly zone ("Odesa") with the data from some other magnetic observatories.

5. The complete content of the magnetic storms catalog will be presented on the website of the S. I. Subbotin Institute of Geophysics of the National Academy of Sciences of Ukraine and the Institute of Radio Astronomy of the National Academy of Sciences of Ukraine.

\section{REFERENCES}

1. ORLIUK, M., SUMARUK, YU., SUMARUK, T., ROMENETS, A. and MELNYCHUK, I., 2009. Geomagnetic observatories of the Ukraine: equipment, measurement practice and data interpretation. In: GEODETIC AND GEOPHYSICAL RESEARCH INSTITUTE OF THE HUNGARIAN ACADEMY OF SCIENCES. The IAGA 11th Scientific Assembly. Sopron, Hungary.
2. SOBITNYAK, L. I., RYABOV, M. I., SUKHAREV, A. L., ORLYUK, M. I., ROMENETS, A. O. and SUMARUK, YU. P., 2018. The catalog of magnetic storms for Odessa magnetic anomaly zone. Odessa Astronomical Publications. vol. 31, pp. 163-166. DOI: 10.18524/18104215.2018.31.146662

3. SOBITNIAK, L. I., RYABOV, M. I., SUKHAREV, A. L. and PANISHKO, S. K., 2017. Structure of Variability Indexes of Cosmic Weather as Applied to Data Monitoring of Fluxes of Radio Sources at the "URAN-4" Radio Telescope. Radio Phys. Radio Astron. vol. 22, no. 4, pp. 294-303. (in Russian). DOI: 10.15407/rpra22.04.294

4. RYABOV, M. I., SUKHAREV, A. L., ORLYUK M. I., SOBITNYAK, L. I. and ROMENETS, A. A., 2019. Comparative Analysis of Geomagnetic Disturbances in the Odessa Magnetic Anomaly Area in the 24th Solar Activity Cycle. Radio Phys. Radio Astron. vol. 24, no. 1, pp. 68-79. (in Russian). DOI: 10.15407/rpra24.01.068

5. SUKHAREV, A .L., ORLYUK, M. I., RYABOV, M. I. and ROMENETS, A. A., 2018. On the First Results of Measurements of Geomagnetic Short-Period Field Variations in the Odesa Magnetic Anomaly Zone with a Second-Long Resolution. Radio Phys. Radio Astron. vol. 23, no. 2, pp. 116-127. (in Russian). DOI: 10.15407/rpra23.02.116

Л. І. Собітняк ${ }^{1}$, М. І. Рябов ${ }^{1}$, М. І. Орлюк ${ }^{2}$, А. Л. Сухарєв $^{1}$, А. О. Роменець ${ }^{2}$ Ю. П. Сумарук ${ }^{2}$, А. О. Пилипенко ${ }^{1}$

${ }^{1}$ Обсерваторія “УРАН-4”, Радіоастрономічний інститут НАН України,

вул. Маразліївська, 1 в, Астрономічна обсерваторія, м. Одеса, 65014, Україна

${ }^{2}$ Інститут геофізики ім. С. І. Субботіна НАН України, пр-т Академіка Палладіна, 32, м. Київ, 03680, Україна

АНАЛІЗ КАТАЛОГУ МАГНІТНИХ БУР ДЛЯ ДАНИХ МОНІТОРИНГУ ПОТОКІВ ВИПРОМІНЮВАННЯ РАДІОДЖЕРЕЛ НА РАДІОТЕЛЕСКОПІ УРАН-4 В ЗОНІ ОДЕСЬКОЇ МАГНІТНОЇ АНОМАЛІЇ

Предмет і мета роботи: Складання цифрового каталогу магнітних бур в зоні Одеської магнітної аномалії для виявлення причин зміни рівня потоків випромінювання космічних радіоджерел за даними спостережень на радіотелескопі УРАН-4.

Методи і методологія: Від 1987 р. та дотепер на радіотелескопі "УРАН-4" Одеської обсерваторії Радіоастрономічного інституту НАН України виконується моніторинг потоку випромінювання потужних галактичних і позагалактичних радіоджерел. Програма моніторингу включає спостереження радіогалактик 3С274, 3C405 і залишків наднових 3С 144, 3С461. Зміни рівня потоків випромінювання радіоджерел визначаються станом іоносфери, обумовленим зміною космічної погоди. 31948 р. в геомагнітній обсерваторії “Одеса” Інституту геофізики НАН України виконуються вимірювання варіацій магнітного поля Землі. Одночасно реєструються вимірювання трьох елементів магнітного поля: горизонтальна складова $(H)$, вертикальна складова $(Z)$ і схилення $(D)$. 
Результати: За даними геомагнітної обсерваторії “Одеса” складений цифровий каталог магнітних бур для періодів моніторингу потоків потужних космічних радіоджерел, виконаного на радіотелескопі “УРАН-4”. Для магнітних бур у періоди моніторингу 1987-1995 рр. та 2000-2009 рр. вказані дата і час початку та закінчення магнітної бурі, тривалість магнітної бурі, значення амплітуд трьох елементів магнітного поля, $H, Z \mathrm{i} \mathrm{D}$, та характеристика типу магнітної бурі. Геомагнітна обсерваторія “Одеса" розташована поблизу зони магнітної аномалії. Для виявлення відмінностей у проявах геомагнітної активності, що виникають внаслідок існування магнітної аномалії, виконано порівняння геомагнітних збурень, зареєстрованих в обсерваторіях "Одеса" та "Москва" (IЗМІРАН, Росія). Показано, що сумарна щорічна тривалість магнітних бур в Одесі більша, ніж у Москві. Це демонструє особливу роль магнітної аномалії в розвитку геомагнітних збурень.
Висновок: Створено цифровий каталогу магнітних бур в зоні Одеської магнітної аномалії у періоди 1987-1995 pp., 2000-2009 pр. та планується завершення роботи над повним каталогом магнітних бур, зареєстрованих в обсерваторії "Одеса" упродовж усього безперервного періоду моніторингу космічних радіоджерел на радіотелескопі УРАН-4, з метою виявлення впливу геомагнітної активності на стан іоносфери та зміну рівня потоків випромінювання космічних радіоджерел. Ці дослідження доповнені порівняльним аналізом геомагнітних даних обсерваторії “Одеса” і даних інших геомагнітних обсерваторій.

Ключові слова: сонячна активність, моніторинг мінливості радіоджерел, магнітні бурі, каталог магнітних бур, магнітна аномалія

Received 19.10.2020 